\title{
Perceived Social Support of Patients Involved in the Psychotherapeutic Treatment
}

\author{
Mirta Vranko', Irena Velimirović ${ }^{2}$, Tihana Jendričko $^{1}$ \\ ${ }^{1}$ University Psychiatric Hospital Vrapče, Zagreb, Croatia, ${ }^{2}$ Clinical Hospital Center Rijeka, Rijeka, \\ Croatia
}

\begin{abstract}
Paper is theoretically grounded in the model of social support. The aim of presented research is to gain insight in the perceived level of social support for people in hospital conditions due to the diagnostic criteria and forms of treatment. The proposed model is a multi-source support model. The sample of the study consists of 51 participants who were enrolled in some form of treatment in the University Psychiatric Hospital Vrapče, since the beginning of February to the end of April 2017. Multidimensional Scale of Social Support (MSPSS), was used. The highest score of perceived support is experienced by significant others (M = 5.72). Interestingly, weakest result of the perceived support by participants was obtained on the subscale of support experienced by the family $(M=5)$. Negative significant was found between perceived social support and age; support is negatively related to age. Older participants rated a lower level of support than the younger ones $(-279 *$, Pearson's correlation coefficient). There are no differences or significant correlations in the perception of social support, gender and form of treatment of participants.
\end{abstract}

Key words: social support, psychotherapy, psychiatric social work

Copyright (C) 2021 KBCSM, Zagreb

e-mail: alcoholism.kbcsm@gmail.com • www.http://apr.kbcsm.hr

\section{Introduction}

In a biopsychosocial approach, perceived social support served as a protective factor in psychological adaptation to mental illness. Earlier research [1] shows that low social support is one of the predictors of psychological problems and is associated with depression, anxiety, attention problems, social problems, somatic disorders, and low self-

\section{Correspodence to:}

Tihana Jendričko,MD. PhD.

University Psychiatric Hospital Vrapče

Bolnička cesta 32 Zagreb, Croatia

E-mail: tjendricko@gmail.com esteem. It seems that the role of social support is very important because it is considered a mechanism to fight stressors of life and promote health and well-being [2]. Social support refers to the experience of being valued, respected, cared about, and loved by others who are present in one's life. It can be provided from a variety of sources, such as a family, friends, teachers, community, or any other social group to which it is linked.

Paper is theoretically grounded in the model of social support. The aim of presented research is to gain insight in the perceived level of social support for people in 
hospital conditions due to the diagnostic criteria and forms of treatment. The proposed model is a multi-source support model. This model consists of several sources involved in satisfying recipient needs. Social support has served as a protective factor in vulnerability with regard to the effects of stress on health. House, Landis, and Umberson (1988) according to Barnes (1954) describe forms of social relations not explained by the family or working groups. Social support is a concept that describes the structure, processes, and functions of social relations.

Multiple concepts such as social support are problematic and not easy to summarize it in a short definition. The basic attributes of all definitions of social support are the provider, recipient, support, and the environment in which the exchange can be realized. When there are attributes mentioned, social support may be exchanged.

Social support is described as "support" available to the individual through social relations with other individuals, groups, and the whole community. Theoretical models of social support define the following two important dimensions: (1) structural dimension that includes the size of the network and the frequency of social interactions and (2) a functional dimension with emotional (such as receiving love and empathy) and instrumental (practical help such as gifts, money or child care assistance) with components.

\section{Perceived social support in mental health}

Malkoç, Yalçin, [3] in the study of 309 students find that good outcome is statistically predictable with resilience, coping and social support from family, friends and significant others. The mediation effect shows that so- cial support and coping ability have doubly influenced the relationship between resilience and good outcomes.

When it comes to personality traits, resilience, and social support, Ceobanu and Mairean [4] describe the results of research on those with PTSD. They found a positive relationship between neuroticism and all the symptoms of traumatic stress, while extraversion, openness, and conscience are negatively associated with avoidance and excitement. Moreover, emotional and informative social support moderated the relationship between extraversion, openness, and symptoms of traumatic stress.

Roohafza and associates [5], in a crosssectional study of the epidemiology of a psychological, nutritional and health project with a total of 4658 over the age of $\geq 20$, describes active forms of coping and perceived social support, in particular positive reinterpretation and family social support as a protective factor for depression and anxiety.

Hsieh, Chang, and Wang [6] find that perceived support and advanced education are important in boosting the resilience of nurses who have experienced a physical assault.

Rutter (1987), according to Jooyoung [7], states that marital support is associated with a high level of resilience. Afifi and MacMillan (2011) also show that spouse support as a support to family members and family members who are not close family members influences resilience. Many studies have found that a key factor influencing resilience involves taking care of and supporting a relationship inside and outside the family. Such relationships lead to the development of one's resilience and include the provision of love, trust, and encouragement [8]. 
Jakovljević [9] in the study that involved 1138 participants discusses the psychological health of the unemployed. The research results show that in the case of unemployed people in Croatia, close persons from their social environment are those who often provide social support; but there are large individual differences in perceived support. Women or young unemployed perceive social support more. Education, family responsibilities and the duration of unemployment were shown to have no significant impact on the assessment of social support.

Balić [10] also investigated the link between quality of life, perceived social support and depression in maternity work. In the study, 101 participants were examined after delivery. Social support has not shown a significant predictor of depression, and the reason is the existence of mediation. The results indicate that the domain of mental health is a mediator of the relationship between perceived social support and postpartum depression. The results also show a statistically significant negative association between social support and depression.

The aim of the work involving parents of children with developmental difficulties living in the Dubrovnik-Neretva County [11] was to gain insights into social support and some aspects of parenting. The research has shown the importance of all forms of support: emotional, financial, practical and counselling assistance received within the family, and spousal support is the most important and most prominent. There is somewhat less present support from friends and relatives as well as parental satisfaction with such support. Institutional support and expert support is least represented and parents engaged in the research are least looking for and at least satisfied with it.
Tadinac and associates [12] compared the level of depression and anxiety among psoriasis patients, gastrointestinal diseases, and healthy participants. They tested the impact of perceived social support on a psychological adaptation of patients. The study involved 240 participants. The results have shown that patients with a higher perceived level of social support have lower levels of depression and anxiety.

\section{Methods, results and conclusion}

Multidimensional Scale of Social Support (MSPSS), was used. MPSS is a 12-item scale that measures perceived support from family, friends, and a significant other [13]. MSPSS specifically addresses the subjective assessment of social support adequacy. Respondents answer to items on a 7-point Likert-type scale (very strongly disagree to very strongly agree) and each of the three subscales (i.e., family, friends, significant other) is assessed with four items. The reliability and validity of the MSPSS have been demonstrated across several populations including university students [13-15] pregnant women [16], adolescents living abroad [16], paediatric residents [16], adolescents on an inpatient psychiatry unit [15], and psychiatric outpatients [17]. Terms used to describe sources of social support in the MSPSS were specifically designed to allow respondents to interpret items in ways most relevant to themselves. For example, the items measuring support from a significant other refer to a "special person," which may be interpreted variously to mean a boyfriend/ girlfriend, teacher, counsellor, etc. The use of more specific terms could have weakened the scale (e.g., asking about a boyfriend/girlfriend presumes the existence of a romantic 


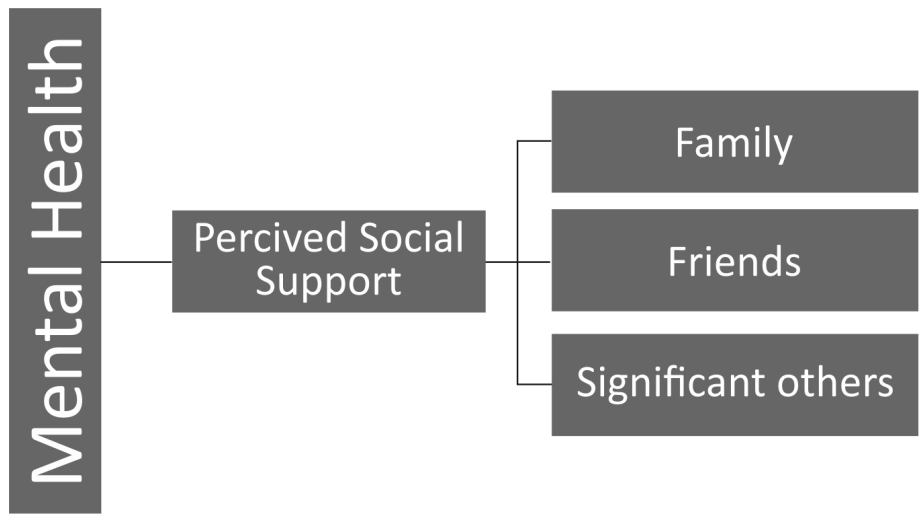

relationship). To calculate subscale scores and total score we added together items (all of them or items related to the scale) and divided them with the number of items. Any mean total scale score ranging from 1 to 2.9 could be considered low support; a score of 3 to 5 could be considered moderate support; a score from 5.1 to 7 could be considered high support.

The sample of the study consists of 51 participants who were enrolled in some form of treatment (in-hospital treatment of the Department for Psychotherapy and daily hospital of above-mentioned Department), in the period from the beginning of February to the end of April 2017. The sample consists of $29.4 \%$ of men and $70.6 \%$ of women. The average age of research participants is 42.45 years. Forms of treatment in which the participants were involved include outpatient care/day-care hospitals (51\%) and hospital treatment (49\%). The most frequent diagnosis was the diagnosis of depressive disorder $(47.1 \%)$ followed by personality disorder $(17.6 \%)$, anxiety depression $(13.7 \%)$, psychosis (11.8\%), stress and PTSD (5.9\%) and bipolar affective disorder (2\%); affective disorder $(2 \%)$. The distribution normal- ity was tested by the Shapiro-Wilk test as it is a small population of participants $(\mathrm{N}=$ 48). The distribution was tested for age, sex, forms of treatment and perceived social support. Shapirov-Wilk's test showed that none of the above variables were normally distributed. Level of support experienced by the family, friends and significant others was studied. Respondents achieve high scores on the scale of experienced total support $(\mathrm{M}=$ 5.34) and support given by friends $(M=5.3)$. The highest score of perceived support is experienced by significant others $(M=5.72)$. Interestingly, weakest result of the perceived support by participants was obtained on the subscale of support experienced by the family $(M=5)$, which value can be categorized as a moderate level of support. The result that raises a question and a potential problem is the negative significant association between perceived social support and age, support is negatively related to age. Older participants rated a lower level of support than the younger ones (-279*, Pearson's correlation coefficient). There are no differences or significant correlations in the perception of social support, gender and form of treatment of participants. Mann-Whintey was used to 


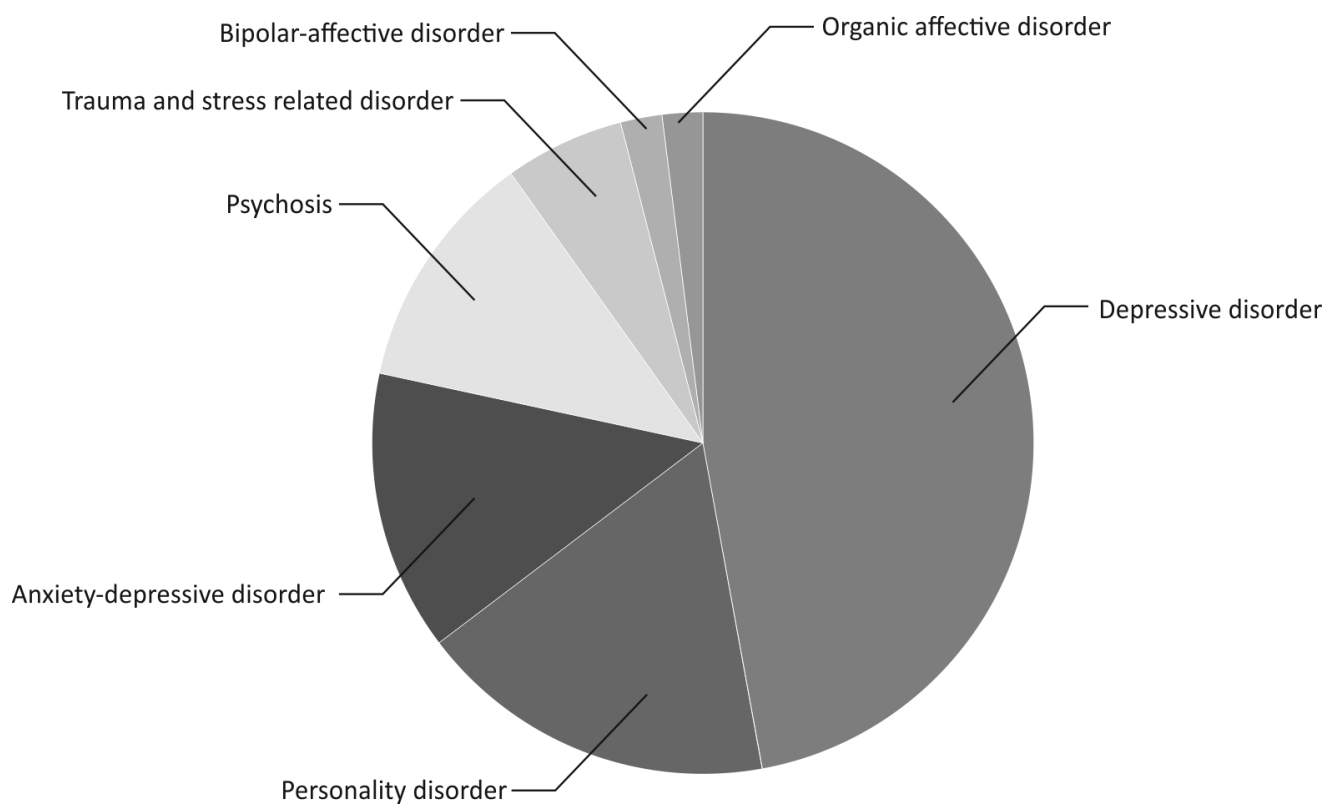

measure are there statistically significant differences in the perception of social support with regard to treatment. There was no statistically significant difference in the perception of social support with regard to treatment (U = 229; $\left.\mathrm{N}_{1}=23, \mathrm{~N}_{2}=25 ; \mathrm{p}>, 05\right)$.

According to the Central Bureau of Statistics and the 2011 census, $17.7 \%$ of the whole population is constituted by the oldest population (65+). This age group is particularly at risk for the development of general psychological but also depressive disorders. The worrying fact is that they are the group that has the least perceived social support. Social support is positively associated with good outcomes of the disease, and also with less susceptibility to disease $[18,19]$. That is why it is necessary to involve families, friends and other people in treatments, or find ways to compensate for the lack of social support.

Perceived social support is, considering literature, often related to the reported severity of psychological and physical symptoms. It is also significant factor in mental health treatment.

From results of study, we suggest more family-related interventions in mental health treatment. Therefore, we recommend particular emphasis for elderly patients.

\section{Acknowledgements}

None.

\section{Conflicts of interest}

None to declare. 


\section{References}

1. Teoh HJ, Rose P. Child mental health: Integrating Malaysian needs with international experiences. In: Amber H, ed. Mental Health in Malaysia: Issues and Concerns. Kuala Lumpur, MY: University Malaya Press; 2001.

2. Steese S, Dollette M, Phillips W, Hossfeld E, Matthews G, Taormina G. Understanding Girls' Circle as an intervention on perceived social support, body image, self-efficacy, locus of control, and self-esteem. Adolescence. 2006;41:55-74.

3. Malkoç A, Yalçin I. Relationships among Resilience, Social Support, Coping, and Psychological Well-Being among University Studentss. Türk Psikolojik Danışma ve Rehberlik Dergisi. 2015;5:35-43.

4. Ceobanu C, Mairean C. The Relation betwwen Personality Traits, Social Support and Traumatic Stress. Revista de cercetare si interventie socijala. 2015;48:17-31.

5. Roohafza HR, Afshar H, Keshteli AH, Mohammadi N, Feizi A, Taslimi M, et al. What's the role of perceived social support and coping styles in depression and anxiety? J Res Med Sci. 2014;19:944-9.

6. Hsieh HF, Chang SC, Wang HH. The relationships among personality, social support, and resilience of abused nurses at emergency rooms and psychiatric wards in Taiwan. Women Health. 2017;57:4051.

7. Jooyoung J. The effect of social support type on resilience [master's thesis]. Alabama, US: University of Alabama; 2012.

8. Newman R. In the wake of disaster: building the resilience initiative of. APA's Public education campaign. In: Grotberg EH, Ed. Resilience for today: Gaining strength from adversity. Westport, US: Praeger; 2003. P. 211-40.

9. Jakovljević D. Nezaposleni u Hrvatskoj: povezanost socijalne podrške i psihičkog zdravlja. Odsjek za psihologiju. Zagreb, HR: Filozofski fakultet Sveučilišta u Zagrebu; 2004.

10. Balić L. Povezanost kvalitete života, socijalne podrške i depresivnosti u rodilja [master's thesis]. Osijek, HR: Filozofski fakultet Sveučilište J. J. Strossmayer u Osijeku; 2015.

11. Leutar Z, Oršulić V. Povezanost socijalne podrške i nekih aspekata roditeljstva u obiteljima s djecom s teškoćama u razvoju. Rev Soc Polit. 2015;22:15376.

12. Tadinac M, Jokić-Begić N, Hromatko I, Kotrulja L, Lauri Korajlija A. Kronična bolest, depresivnost i anksioznost. Soc psih. 2006;34:169-74.

13. Zimet G, Dahlem NW, Zimet SG, Farley GK. The Multidimensional Scale of Perceived Social Support. J Pers Assess. 1988;52:30-41.

14. Dahlem NW, Zimet GD, Walker RR. The Multidimensional Scale of Perceived Social Support: a confirmation study. J Clin Psychol. 1991;47:75661.

15. Kazarian SS, McCabe SB. Dimensions of social support in the MSPSS: Factorial structure, reliability, and theoretical implications. J Community Psychol. 1991;19:150-60.

16. Zimet GD, Powell SS, Farley GK, Werkman S, Berkoff KA. Psychometric characteristics of the Multidimensional Scale of Perceived Social Support. J Pers Assess. 1990;55:610-17.

17. Cecil H, Stanley MA, Carrion PG, Swann A. Psychometric properties of the MSPSS and NOS in psychiatric outpatients. J Clin Psychol. 1995;51:593-602.

18. Cohen S, Syme SL. Issues in the study and application of social support. Social support and health. 1985:3-22.

19. Jemmott JB, Locke SE. Psychosocial factors, immunologic mediation, and human susceptibility to infectious diseases: How much do we know? Psychol Bull. 1984;95:78-108. 


\section{Percipirana socijalna podrška pacijenata uključenih u psihoterapijski tretman}

Sažetak - Rad je teoretski utemeljen na modelu socijalne potpore. Cilj predstavljenog istraživanja je steći uvid u percipiranu razinu socijalne potpore ljudima u bolničkim uvjetima zbog dijagnostičkih kriterija i oblika liječenja. Predloženi model je model podrške iz više izvora. Uzorak studije sastoji se od 51 sudionika koji su primljeni na neki oblik liječenja na Klinici za psihijatriju Vrapče, od početka veljače do kraja travnja 2017. Korištena je Multidimenzionalna skala socijalne potpore (MSPSS). Najveću ocjenu opažene podrške imaju životni partneri $(M=5,72)$. Zanimljivo je da je najslabiji rezultat percepcije podrške od strane ispitanika postignut na subskali potpore koju su doživjeli od obitelj $(M=5)$. Nađena je negativna povezanost između percepcije socijalne podrške i dobi; podrška je negativno povezana s godinama. Stariji sudionici ocijenili su nižu razinu potpore od mlađih (-279*, Pearsonov koeficijent korelacije). Ne postoje razlike ili značajne korelacije u percepciji socijalne podrške, spolu i obliku liječenja sudionika.

Ključne riječi: socijalna podrška, psihoterapija, psihijatrijski socijalni rad 
